\title{
Paradigm Change in Turkish Foreign Policy after Post-Cold War
}

\section{H. Burç Aka*}

\begin{abstract}
The article analyses the change in paradigm of Turkish Foreign Policy with reference to Post-Cold War. The article has two main assumptions: (i) The international system mainly determines the foreign policy of any state (ii) Post-Cold War is a multi-polar international system with three sub-periods. The article understands the strategy and objectives of Turkish Foreign Policy for each sub-period to identify the paradigm change of it. The article concludes that Turkey has adopted a complementary alliance with West in its foreign policy, but endeavored to conduct an ideologist alliance the remainder states of Ottoman Empire after 2008.
\end{abstract}

Key Words: $\quad$ Turkish Foreign Policy, Paradigm Change, Foreign Policy Analysis, Post-Cold War

* Assistant Professor, Department of International Relations, University of Namık Kemal, Tekirdağ, hbaka@nku.edu.tr 


\section{H. Burç Aka}

\section{Introduction}

In the cabinet announced by Ahmet Davutoğlu on August 29, 2014, the assignment of Mevlut Cavusoglu to the Ministry of Foreign Affairs and Volkan Bozkir to the Ministry for European Union Affairs was interpreted as an effort on the part of Turkey to return to a Western-oriented | 56 foreign policy. Although the debates on the paradigm shift in Turkey's foreign policy have started to flare up again, however, every action and/or discourse concerning foreign policy cannot be interpreted as a paradigm shift. Therefore, it is obvious that such interpretations should be made after careful analysis.

In the studies explaining the change in Turkish foreign policy at the actor level, both Davutoglu and the Justice and Development Party (JDP) stand out as the units of analysis. The common point of the analyses that places Davutoglu in the center is based on the concepts proposed by him such as zero problems with neighbors, multi-dimensionalism and multilateralism in foreign policy, rhythmic diplomacy. ${ }^{1}$ On the other hand, among the studies that perceive the government of the JDP as the main driving force of the change in foreign policy, some argue that the JDP developed a foreign policy approach by taking the global economic conditions into account that led to a change in Turkish foreign policy. ${ }^{2}$ Others explain the change in foreign policy in terms of identity. ${ }^{3}$ The actor level analyses (whether it is Davutoglu or the JDP) push the role of the international system aside regarding the changes that occurred in Turkey's foreign policy.

There are also studies explaining the change in Turkish foreign policy both at the international system level and actor level. ${ }^{4}$ As these studies, implicitly or explicitly, assume that the paradigm shift in Turkish foreign policy started with the JDP's coming to power, they tend to ignore the changes that took place in the 1990s. However, the international system has undergone a structural change with the end of the Cold War in 1989 and Turkish foreign policy has started evolving at that time in order to adapt to the change.

The studies that explain the change in Turkey's foreign policy only at the international system level are very limited. Among them, the studies by Tezcur ve Grigorescu are noteworthy. They evaluated the change in Turkey's foreign policy following the end of the Cold War by means of a political-economic analysis and reached the conclusion that Turkey did not break away from a Western-oriented foreign policy. ${ }^{5}$ However, the studies that deal with the post-Cold War Turkish foreign policy from a perspective of international systemic changes with a holistic approach are not yet at a satisfactory level.

This article aims to explain the shift and renewal in Turkey's foreign policy paradigm. The article is important as it describes the effects of the international systemic changes after the Cold War on Turkish foreign policy with an integrative approach. Thus, it will be possible to trace the changes in Turkish policy in an uninterrupted manner. The article will be developed within the framework of the main question of how international systemic changes following the end of the Cold War affect Turkey's foreign policy paradigm. In this framework, answers to the following sub-questions will be sought: i) How does the post-Cold War international systemic change affect Turkey's foreign policy strategy? ii) What are the objectives of the foreign policy strategy which is affected by the international systemic change?

In the first part of the article, the basic concepts will be explained. In the second part, an analytical framework will be established. In the third part, the paradigm shifts in Turkish foreign policy will be traced in terms of the sub-periods of the post-Cold War international system. And in the last part, an evaluation of the paradigm shifts in Turkish foreign policy will be made. 


\section{Conceptual Framework}

\section{The Post-Cold War}

The term "post-Cold War" is a concept used to emphasize the fact that the bipolar international system, shaped in accordance with the principles of the Yalta Conference (1947), ended with the Malta Conference (1989) and refer to a new world order. However, there are disagreements about the duration of the post-Cold War era. While one view asserts that the post-Cold War era ended with the terrorist attacks on September 11, 20016, another view argues that the post-Cold War international system is still in progress. ${ }^{7}$ This article deals with the Cold War as an ongoing international system and divides the post-Cold War era into three sub-periods. The first period which may be called the "New World Order" lasted until the attack of al Qaeda terrorist organization at the World Trade Center on September 11, 2001. While the Russia-Georgia War (2008) closed the second period which may be called "post-September 11", it also signaled the start of the third period of the post-Cold War system. ${ }^{8}$

One cannot talk about a consensus regarding the nature of the post-Cold War international system. One group views the post-Cold War international system as an international environment consisting of a single center of power. ${ }^{9}$ In the post-Cold War international system, the U.S. was touted as the first truly global power. ${ }^{10}$ However, the U.S., considered to be the world's greatest power from a perspective of political, economic, military and technological point of view, was not able to bring about a transformation in the international system commensurate with its might. For example, in the permanent membership structure of the UN Security Council a restructuring establishing the U.S. as a hierarchical power did not materialize.

Another group argues that the post-Cold War international system is a balance of power, acting on the premise that the emergence of the European balance of power in the 18th and 19th centuries resembles the post-Cold War situation. ${ }^{11}$ Indeed, the fact that the U.S. was attacked on its homeland undermines the judgment that it is the only power in the international system. In the article the post-Cold War international system is treated as a balance of power in terms of both the structural features and behavioral patterns of the governments and is divided into three subperiods.

\section{Turkish Foreign Policy}

In the article Turkish foreign policy concept is confined to its three dimensions. First, as it is focused on the post-Cold War international system, the Turkish foreign policy between the years of 1989-2013 is discussed. Furthermore, as mentioned before, Turkish foreign policy is analyzed according to the three sub-periods of the international system. Second, the concept has been categorically restricted, and it has been focused on the strategy and objective dimensions of Turkish foreign policy. Finally, Turkish foreign policy has been evaluated within the context of a medium-sized state's foreign policy.

To summarize, in the article the concept of Turkish foreign policy refers to a foreign policy paradigm developed by a medium-sized state in order to adapt to the post-Cold War conditions as well as the strategies and objectives it defines accordingly.

\section{Foreign Policy Paradigm and the Shift}

Paradigm can be defined as "a philosophical and theoretical framework of a scientific school or discipline within which theories, laws, and generalizations and the experiments performed in 
support of them are formulated." 12 As a result of the circumstances or preferences, when the dominant paradigm begins to lose its effect a new paradigm emerges. However, paradigm shifts do not occur in a short period of time.

Starting with this definition, foreign policy paradigm can be defined as the basis of a state's foreign policy approach; because states base their foreign policies on a fundamental paradigm in order to reach their objectives. In the light of the factors such as the state's regime, geo-political position, history, economic and political activities, this paradigm is shaped according to its national interests extending over a broad range of periods. ${ }^{13}$ When foreign policy paradigms lose their effectiveness, their replacement or revision is inevitable. However, the historical evidence shows that the cost of discontinuous and radical changes in foreign policy paradigms turns out to be high.

Change in foreign policy may occur depending on the decision-making preferences of foreign policy actors, intergovernmental relations, change in the balance of power in the international system. ${ }^{14}$ However, the most important determinant of a change in a state's foreign policy paradigm is the nature of the international system. Turkey, following the end of the Cold War, has attempted to redefine its position and role in the international system. In short, in the article the foreign policy paradigm is described as the new foundation of Turkey's foreign policy approach after the Cold War; whereas the paradigm shift in foreign policy is associated with the renewal or revision of the position and role in the international system.

\section{Analytical Framework}

In foreign policy analyses, a dual distinction may be made between a state-centered approach and pluralistic approach which takes the non-state actors into consideration. ${ }^{15}$ In the article a statecentered approach is preferred. Therefore, in order to establish an analytical framework foreign policy outcomes of the states must be used and the set of variables that help the analysis of these outcomes must be defined.

The said outcomes can be analyzed using one of the following set of variables: i) policy makers, ii) aims, iii) principles, iv) power to implement, v) foreign policy context ${ }^{16}$; or i) foreign policy orientation, ii) national role, iii) objectives, iv) actions ${ }^{17}$; or i) orientation, ii) actions and plans, iii) behavioral pattern. ${ }^{18}$ Among these, the set of variables consisting of orientation, actions and plans, behavior pattern has been preferred in reviewing Turkey's post-Cold War foreign policy approach. While the orientation variable deals with Turkey's foreign policy approach; actions and plans variable focuses on Turkey's foreign policy objectives.

In line with the assumption that Turkey has built its post-Cold War foreign policy orientation on the alliance strategy, the article does not take disconnectedness, neutrality and isolationism into consideration. This study evaluates Turkey's alliance strategy in terms of alliances that serve identical interests, alliances that serve complementary interests and alliance strategies that serve ideological interests. ${ }^{19}$

In the analysis of Turkey's post-1989 policy objectives, the following categories of objectives were utilized: i) objectives for self-preservation, ii) security objectives, iii) welfare objectives, iv) prestige objectives, v) objectives to establish and develop an ideology. ${ }^{20}$ Given that Turkey is a medium-sized state, objectives aimed at obtaining power directly are deemed unrealistic and hence excluded from the categories of objectives.

\section{Turkish Foreign Policy and the New World Order Period (1989 - 2001)}

The most prominent feature of the first period of the post-Cold War in terms of security is the ending of military competition based on ideological polarization. New security threats were 
defined as difficult to predict and assess, multi-dimensional and multi-faceted and seen as the negative consequences of instabilities arising from serious economic, social and political problems, including hostilities and border disputes faced by many countries in Central and Eastern Europe. ${ }^{21}$ The security threats in the New World Order were not only confined to military areas but also covered other areas that produced instability and risk.

A political feature of the period was the rise of liberal democracy as a consequence of separation and unification movements. The states of the old system such as the USSR, Yugoslavia and Czechoslovakia were buried in history and new states emerged from their remnants. In the New World Order era ethnic and religious identities emerged as factors not to be ignored both in domestic and foreign policy. Parallel to this development, while it may appear contradictory, one can state that the integration processes gained momentum. One may observe that the European integration was elevated to a higher level in order to adapt to the changing conditions in the international system and, with the European Union (EU) agreement, the member states took steps in the direction of deeper integration. Similarly, the North American Free Trade Area (NAFTA) and the Association of Southeast Asian Nations (ASEAN) are examples of integration movements outside Europe.

During the first period of the post-Cold War liberal democracy was seen as a guarantee of international security. In speeches made by Margaret Thatcher, Prime Minister of the United Kingdom at that time, in the Czechoslovak Federal Assembly in 1990 and William Jefferson Clinton, the former U.S. president, at the 50th anniversary events of the United Nations (UN) in 1995, they extolled the democratic regimes in the name of international security. ${ }^{22}$ Because historical experiences showed that the states governed by liberal democracy did not revert to war in the solution of their conflicts.

The economic characteristic of the period was the globalization. The globalization presented neo-liberal policies as the new standard of economies and further strengthened the international economic organizations such as the International Monetary Fund and the World Bank. The goal of the globalization was to ensure growth in the less-developed/developing economies by fueling the global trade. The emerging economies were dependent on the inflow of foreign capital due to the lack of savings to finance their economic growth. While this situation was the principle cause of continual economic crises experienced at frequent intervals, it also created an obstacle to the medium-sized states such as Turkey to pursue an autonomous foreign policy.

\section{Strategy of Turkish Foreign Policy in the New World Order}

Ankara did not make a fundamental change in its foreign policy strategy in the new era. There were three reasons behind this. First, since the $19^{\text {th }}$ century both the Ottoman and Republican era foreign policy makers did not adopt a foreign policy strategy contrary to the ideal of becoming a European state. Indeed, even Necmettin Erbakan, the first Prime Minister coming from the tradition of political Islam, did not consider Islamizing foreign policy. During Erbakan's term, continuity rather than change was the norm in the foreign policy strategy. ${ }^{23}$ The diverse issues such as relations with Israel, Peace Operations II, the Customs Union with the EU and Cyprus confirms the continuity. ${ }^{24}$ Second, in a multi-polar system it was a rational choice for Turkey to side with the West, the U.S. in a narrow sense, as being a member of the bloc that won the war would bring prestige to Turkey's foreign policy. Third, Turkey, having transformed its economy in accordance with neo-liberal policies since the 1980s, was integrated with the West more closely. Therefore, it did not seem rational for Turkey to look for an alternative to its Westernoriented foreign policy strategy.

However, in the post-Cold War era when the threat of the USSR expansionism and communism which were regarded as NATO's reason for existence were eliminated, there was a prevailing conviction in some circles that Turkey's geo-strategic importance had diminished. ${ }^{25}$ 
Obviously, without any attributed geo-strategic importance, it would be very difficult for medium-sized states such as Turkey to be a key actor in the international system.

As Turkey was looking for a way to convey the message to its allies that its geo-strategic importance in the new international system still continued, the 1991 Gulf crisis came to the rescue. Following the invasion of Kuwait, Turkey proved its geo-strategic importance to the West by taking an active role in the formulation, adoption and implementation of the sanctions against Iraq. ${ }^{26}$ If Turkey had not been able to convince its allies of its strategic importance, the West might have reduced economic and military aid and Turkey could have faced a tougher attitude on diverse issues such as Cyprus and human rights. ${ }^{27}$

NATO, in its strategy for the New World Order, assessed the security issue in a broad perspective and adopted not only military but also preventive measures such as dialogue, cooperation, conflict prevention, crisis management to ensure the security of its allies. ${ }^{28}$ NATO's new strategy concept had a Eurocentric perspective. However, the instabilities occurring in regions outside Europe harbored security risks that could not be ignored.

In order to implement its foreign policy strategy in the new era, Turkey was ready to act as a buffer against threats that could be directed at the West and protect the interests of the West in the Middle East, the Caucasus, the Black Sea and Central Asia. This role would complement NATO's new strategy. Despite its Muslim population, its level of Westernization, culture of democracy, secularism, free market economy all provided great advantages for Turkey. Moreover, Turkey had ethnic and/or religious ties with the said regions. As a NATO member, Turkey would function as a bridge between the West and the others. In return for securing military, political and economic support of the West, Turkey set the goal of its new foreign policy strategy as to become a regional power.

Richard Holbrooke's assessment that Turkey was situated at the juncture of almost every issue of importance to the U.S. on the Eurasian continent heralded the role of Turkey as a regional power. Two years after this statement, geo-strategist Brzezinski, whose influence on the former U.S. Secretary of State Albright is well-known, placed the Eurasian region among the US's strategic priorities and described Turkey and Russia as the two powers in the region.

To understand the turning points and innovations in Turkey's foreign policy strategy, it is sufficient to look at its strategy for Central Asia and the Caucasus. First, the claim by Turkish decision makers that the 21 st century will be the century of the Turks is a matter that lies outside the realm of traditional foreign policy. Namely, "Turkey strictly adhered to Ataturk's policy that defined Turkish national identity exclusively with reference to the Turks living within the borders of the country and ruled out the possibility of irredentism." ${ }^{29}$ However, in this period the Turkishness was interpreted as an integrative identity.

As a result, in the New World Order, Turkey shaped its foreign policy strategy in accordance with the Western-oriented complementary alliance policy. While ensuring the protection and sustainability of its Cold War allies' interests in the regions close to Europe, Turkey set the objective of becoming the rising regional power in Central Asia and the Caucasus as the mainstay of its foreign policy.

\section{Objectives of Turkish Foreign Policy in the New World Order}

In setting the foreign policy objectives for the new era, Ankara had to simultaneously evaluate several developments ranging from the European integration process to the emergence of Turkishspeaking countries in the Caucasus and Central Asia, from the tragic developments in the Balkans to the instability and conflicts in the Middle East and the Caucasus. ${ }^{30}$ Because the external threats directed at Turkey in the 1990s originated from these regions. 
Being ostracized by the European Union, continuation of the military and irredentist acts against its territorial integrity by Syria, Iraq and Iran, Greece's attempt to step up the campaign pursued against Turkey to new dimensions in order to take advantage of both of the developments and finally Russia's acceleration of its efforts to prevent the passage of Caspian basin oil through Turkey by exerting its power over its Southern neighbors. ${ }^{31}$

There were also internal threats to Turkey's own security such as separatist terrorism and ethnic conflict. Sukru Elektag summed up the threats to Turkey's security as a war on two and a half fronts: Greece and Syria as the two main fronts; PKK terrorist organization as the half-front. ${ }^{32}$

One of the disputes between Turkey and Syria is the water issue. The dams Turkey built within the scope of the Southeastern Anatolia Project (SAP) also allowed the control of the water flow to Syria over Euphrates. However, Syria was in great need of Euphrates water for irrigation, agriculture, drinking water, production and hydro energy. Syria was disturbed over Turkey's control of the water through the SAP. ${ }^{33}$ The other issue is about Hatay which is situated on the coast of the Mediterranean, because "Syria has not yet politically and culturally accepted the fact that Hatay lies within the borders of Turkey." 34

During this period military deterrence was limited due to the tactical ballistic missile threats directed at Turkey by Syria. ${ }^{35}$ However, Syria chose to use the PKK terrorist organization as leverage against Turkey. Turkey's move against this was to strengthen its relations with Israel. For example, "as demonstrated by the joint naval exercises carried out in the Mediterranean in January 1996, the growing military cooperation between Turkey and Israel could essentially be regarded as a squeeze play against Syria" ${ }^{36}$ If we exclude the year 1999, Turkey tried not to escalate the crises with Syria to a hot conflict; because Turkey was aware that the creation of an environment of conflict would only serve Greece to realize its objectives in the Aegean. ${ }^{37}$

The first crisis in this period broke out following the proclamation of the Joint Defense Doctrine between Greece and Cyprus in 1994; because, according to the doctrine, Greece would be creating a common defense area and regarding an attack on Greek Cyprus as a cause for war. Also, in this doctrine, the declaration of intent by the two states that they would decide and act together in the international arena would affect Turkey's EU process closely.

The Imia crisis experienced in 1996 was the second crisis. Two member states of NATO came to the brink of war. ${ }^{38}$ The tension between the two states was resolved by means of an agreement reached between the parties at the NATO Summit held in Madrid on July 8-9, 1997. According to the agreement, both parties should "refrain from the use of force and respect each other's vital interests in the Aegean." 39 At a time when NATO's expansion in Central and Eastern Europe provoked the reaction of the Russian Federation, it was only natural for the allies to step in and lower the tension. This agreement also demonstrated the capability of the balance of power system to influence the foreign policies of the states.

In the New World Order era Turkey's prestige-oriented foreign policy are undoubtedly the relations with Azerbaijan and the Turkish Republics in Central Asia; because Turkey, as a democratic state with a free market economy, was expected to be a model for the development of the five new republics, and these advantages would help Turkey to become a regional power. ${ }^{40}$ Indeed, the existence of historic, cultural and religious ties between Turkey and the Turkish republics, being part of the prosperous West and its potential to establish a bridge between the West and the Turkish Republics were increasing the attractiveness of the Turkish model. Moreover, the former U.S. Secretary of State Baker, during his visits to the capitals of the region, urged the Turkish Republics to adopt the Turkish model for political and economic progress. ${ }^{41}$

However, the Turkish model was problematic. First, the similarity of language, culture, ethnicity between Turkey and the Turkish Republics were more heterogonous than it was thought. Second, as these states were newly freed from Moscow, they did not want a new protector. Third, there were serious conflicts of interest among the Turkish Republics. Fourth, Turkey had pledged $\$ 3$ billion in aid to the Turkish Republics; but its economy was not strong enough to handle an aid 
at this scale. Finally, Turkey's ambition to become a model in the region was limited by the alternatives of Iran and Russia. ${ }^{42}$

To create an energy corridor between the West and the East and be part of the European integration are among Turkey's foreign policy objectives aimed at increasing its welfare. Following the collapse of the USSR, the Caspian basin oil and gas potential was whetting appetites. The characteristic complicating the geo-political importance of the region was the fact that all the states that had newly gained their independence did not have direct access to the sea and hence could only realize the export potential of their energy resources through the transit pipelines over neighboring countries. ${ }^{43}$

Turkey, grabbing its share from the fierce competition in the transport of oil and gas to the European consumer markets, was aspiring to reduce the economic burden arising from its energy needs and its dependence for energy on Russia in the medium term. Turkey's objective was to lead the way in the realization of the Baku-Tbilisi-Ceyhan (BTC) crude oil pipeline project for the distribution of Azerbaijani oil. In addition, the fact that when the pipeline became a reality, it would also provide an alternative outlet for Kazakhstan and Turkmenistan to the global market over time makes the importance of the project for Turkey more understandable. ${ }^{44}$

If Turkey obtained what it wanted from the fierce competition it entered in the transportation of Azerbaijani oil, it owed this to its foreign policy at that time. Because the Russian Federation and the oil companies of the international consortium with BP leading the way were supporting the Baku-Grozny pipeline for strategic reasons and cost concerns, respectively. On October 9, 1995, with some support by the U.S. government, it was decided that the transportation of the so called early oil were to be carried through two separate pipelines. These were Baku-Grozny-Novorossiysk and Baku-Tbilisi-Batumi pipelines. ${ }^{45}$ This was a great success for Turkish foreign policy. The first shipment of oil from the Baku-Tbilisi-Batumi pipeline loaded onto a tanker on June 4, 2006 at the Ceyhan Marine Terminal, and as of October 12, 2012 the amount of oil exports realized through the said pipeline exceeded one and a half billion barrels. ${ }^{46}$

Turkey, in a journey that started with the Ankara Agreement on September 12, 1963 towards the European integration, made an appropriate move to secure its economic interests by putting the Customs Union Agreement into effect with the EU on January 1, 1996. Accordingly "Turkey will have access to the European market under practically the same terms with the members of the EU". ${ }^{47}$ Closer economic integration with the EU was expected to have a positive effect on Turkey's relations with the Central Asian and Middle Eastern countries.

In the New World Order era, Ankara adopted a security-oriented approach in its foreign policy due to not only being situated in an unstable region but also problematic relations with the neighbors. Turkey's prestige-oriented policies appear to have progressed lamely due to the weaknesses arising from its insufficient economic and political power.

\section{Turkish Foreign Policy and the Post-September 11 (2001 - 2008)}

The suicide attacks carried out by Al Qaeda terrorist organization on September 11, 2001 against the targets in the United States proved that every actor, including the U.S., in the international system is under threat. This attack revealed the following key issues regarding the new era:

One is the activities of international radical Islamic terrorism targeting the 'Western' civilizations, and the other one is the policies implemented in the name of combating terrorism. This situation which creates a dilemma feeding each other led to the increase of anti-terror measures by the West on one hand and becoming more exposed to terrorism as a result of the increased measures on the other hand. ${ }^{48}$ 
In its strategic concept updated in 1999, NATO failed to foresee that international terrorism would become a threat at the global level. ${ }^{49}$ The West was caught unprepared for the threat of terrorism. The U.S. aimed to pursue its fight against terrorism within the framework of the Bush doctrine which was based on pre-emptive war, unilateralism and spreading democracy. ${ }^{50}$ Indeed, the Iraq War in 2003 was a pre-emptive war experience that resulted in the overthrow of the Saddam regime. However, many EU member states of NATO were hesitant in their approach to pre-emptive war in the fight against terrorism and advocated the transformation of the Middle East with constructive dialogue.

On the other hand, just as in the New World Order era, in the post-September 11 period democracy was also regarded as critical to international security. The difference from the previous period was that, when necessary, democracy should be established by means of force as was the case in the Central and Eastern European examples as opposed to incentives; because fundamentalist terrorism was growing stronger with the support of the undemocratic regimes in the Middle East.

During the period between 2001 and 2008, the world economy entered a period of expansion. Thanks to the accumulation of excess liquidity in the global economy, many developing economies such as Turkey had the opportunity to finance their growth using lowinterest loans. In addition, with China leading the way, Russia, Brazil and India became the rising stars of the global economy; as the BRIC countries, they rose to the ranks of the world powers to be reckoned with.

\section{Strategy of Turkish Foreign Policy in the Post-September 11}

After the September 11 attacks, some decision makers in Ankara led by high-ranking officers believed that "the U.S. would needed Turkey for its interests and for the control of Eurasia" following the end of the Cold War. ${ }^{51}$ It is debatable to what extent such a conviction is commensurate with the realities of the post-September 11 period. First of all, Turkey was disappointed in the struggle with the Russian Federation and Iran to become the regional power in Central Asia and the Caucasus. Furthermore, "following September 11, 2001 the United States, prior to and after its campaign in Afghanistan, acquired airbase facilities in Uzbekistan and established a military relationship with Tajikistan and Kyrgyzstan. It could thus move in Turkic Central Asia on its own without Turkey's support." 52

However, the post-September 11 conditions in the world paved the way for Turkey to play a strategic role arising not only from its geographical location but also its uniqueness of being neither/both a Western nor/and Eastern country, because from the perspective of the Western powers, a major impact of September 11 involved the need to increase dialogue and mutual understanding with the Islamic world. Such a dialogue was not only important for the United States, but it was also crucial for the European Union which has a significant Muslim minority within its borders and is geographically much closer to the Muslim world than the United States. ${ }^{53}$

In order to establish a bridge of dialogue between the Muslim World and the West, "NATO member Turkey with a Muslim population, having a free market-oriented economy and governed by a secular democratic regime despite all its shortcomings, was a very suitable actor against Al Qaeda's jihadist project". ${ }^{54}$

Turkey's foreign policy strategy revised according to the Islamic model or moderate Islamic principles led to a significant cleavage in the country. The notion of Turkey serving as an Islamic model to the Middle East in accordance with the interests of the U.S. was rejected by the staunchly secular military-bureaucratic establishment at that time. ${ }^{55}$ Whereas, the JDP that came to power in 2002, believing an Islamic democracy would be possible, embraced the model attributed to Turkey. 
As a natural consequence of the new foreign policy strategy, Turkey had to pay attention to its relations not only with the U.S. but also the relations with the EU which were politically neglected in the previous period; because, after the September 11 attacks, there were serious differences of opinion between the Atlanticists and the Europeanists in NATO regarding the policies on international security and terrorism in particular. For example, the war in Iraq led to a crisis even in NATO's European pillar. In the war against Iraq, the United Kingdom, Spain, Italy

| 64 and Portugal along with the EU candidate countries in Central Europe such as Poland and Czech Republic sided with the US. In contrast, France, Germany, Belgium and Luxembourg formed the bloc that was against the use of force in Iraq. ${ }^{56}$

Turkey was able to wisely exploit the differences of opinion in NATO thanks to its strategic potential in the new era. One observes this during Turkey's EU membership process. After the attacks on September 11, 2001 and prior to the 2003 Iraq War, Turkey, while having the George Bush administration actively lobby on its behalf for the start of the accession negotiations on one hand ${ }^{57}$ and refusing the ballot that would allow the deployment of the U.S. soldiers in Turkey on the other hand, shattered the image of a potential Trojan horse for Washington in the EU. ${ }^{58}$ Thus, Turkey ensured the decision regarding its candidate status at the 2002 Copenhagen Summit to be made in 2004.

It appears that Turkey set its post-September 11 foreign policy strategy on the basis of complementary alliance policy. Ankara's foreign policy was still Western-oriented but was based on a "Muslim model state" concept. Thus, Turkey could establish a bridge between the Muslim world and the Western world. ${ }^{59}$ In addition, Turkey configured its foreign policy strategy by taking into account the balance between democracy and security. While Turkey became a strategic partner of the U.S. within the context of the Greater Middle East Project, it also succeeded to start the full membership talks with the EU in 2005 by transforming itself in accordance with the Copenhagen criteria since 1999. Thus, Turkey managed to increase the credibility and appeal of the model it proposed for the Middle East.

\section{Objectives of Turkish Foreign Policy in the Post September 11}

If the problematic relations with its bordering neighbors continued, Turkey realized that it would not be able to implement the actions and practices commensurate with its new foreign policy. Because Ankara was aware that it was unable to perform its role satisfactorily in Central Asia and the Caucasus when it was preoccupied with tense relations with its bordering neighbors Greece and Syria. In fact, prior to September 11, Turkey, having reached its goal on the terror front with the capture of the leader of the PKK terrorist organization, softened its approach in its relations with Greece and Syria. For example, Turkey, acting together with Greece in 2002, had tried to contribute to the peace building process between Israelis and Palestinians. The 10th President Sezer's attendance at the funeral of the Syrian leader Hafez al-Assad in June 2000 and the official visit he made to Iran two years later were examples of Turkey's search for stability in its relations with its neighbors.

The JDP that came to power following the general elections on November 3, 2002 also continued to establish positive relations with the neighbors. Even using an exaggerated but appealing principle such as zero problems with neighbors, Turkey was pursuing its foreign policy objectives aimed at ensuring the existence and security of the country. The concept of zero problems with neighbors should not be interpreted as the ultimate solution to the traditional problems with the neighboring countries. The goal was to prevent the traditional problems to impede the development of bilateral relations and ensure an environment of stability in the region. Narrowing the areas of conflict and problem in the relations with the neighbors, and expanding the areas of cooperation in return, Turkey would weaken the argument that it could import instability to the EU over its neighbors; Turkey would also be able to focus on the welfare and prestige-oriented foreign policies that would serve its objective of becoming a regional power. 
In order to be able to implement the new era policy in a sustainable manner, in its foreign policy, Turkey had to give priority to the goals that would increase the country's welfare; because, during the previous international period, Turkey's lack of economic power was one of the major factors weakening its ambition to become a regional economic power. Turkey, with its multi-dimensional foreign policy principle with its roots going back to the 1990s, aimed at increasing the welfare of the country in the first place and then its prestige in the second place.

The zero problems with neighbors approach created a developing economic interdependence between Turkey and its neighbors. ${ }^{60}$ In bilateral relations with the neighbors, in addition to the prevailing sense of stability in the region, the practice of multi-dimensional policy was providing Turkey with an opportunity to collaborate with the important actors such as the Russian Federation, China, Iran and Brazil. "Particularly the rapidly evolving political and economic relations with Russia during the 2000s were shaped within the framework of 'multidimensional enhanced partnership'.".61

In parallel to the expansion of the world economy in this period, Turkish economy had also entered a growth trend. Turkey was in the position of a capital importing country due to its dependence on domestic demand for growth. ${ }^{62}$ Foreign capital inflows would ensure the sustainability of the growth and thus increase the welfare of the country. Indeed, the multidimensional foreign policy contributed to the economy positively in terms of both foreign capital inflow and direct foreign investment.

During the post-September 11, the relations with the EU were at the very center of the prestige-oriented foreign policy objectives of Turkey. Compared to the previous period, reciprocity was a factor in the balance of benefits in Turkey-EU relations. For the EU, Turkey was an actor that would bring diverse cultures around a common understanding and bestow legitimacy to the EU in the eyes of non-Europeans. If Turkey joined the EU, it would dispel the notion that the EU was a Christian Club and save the EU from being the target of fundamentalist terrorist acts with the legitimacy it would provide to the EU.

Turkey had the potential to strengthen the EU's foreign policy not only in the Middle East but also in the Black Sea region; because, due to its geo-political position, it was of key importance to the security of the EU's energy needs. In short, Turkey's membership would expand the borders of the EU to the Caucasus and the EU would have a greater influence in these regions. ${ }^{63}$

Turkey's excitement over the EU integration was revived after the Helsinki Summit in 1999. Due to the systemic conditions of the post-September 11, Turkey aimed to establish closer and more robust relations with the EU and embarked on a reform and democratization process in this direction. Turkey genuinely supported even the Annan Plan that could solve the Cyprus issue.

The favorable atmosphere created by the relations with the EU bolstered Turkey's confidence to emerge as a civil-economic power in the Middle East. ${ }^{64}$ Turkey showed that it would be possible to bring peace, democracy and economic development to the Middle East associated with instability, authoritarian regimes and economic backwardness. For example, Iran and Syria viewed European Turkey as an opportunity to develop their own relations with the EU. ${ }^{65}$ Similarly, the Arab funds in the Middle East look to Turkey as an EU candidate country worth investing in.

Since the late 1990s Turkey aimed for a foreign policy based on cooperation with its neighbors. However, the post-September 11 conditions in the international system intensified Turkey's efforts to establish favorable relations with its neighbors. In this period Turkey, maintaining moderate relations with the bordering neighbors and regional countries, had the opportunity to concentrate on welfare and prestige-oriented policies. 


\section{Turkish Foreign Policy and the Post-2008}

The Russia-Georgia war that erupted in 2008 signals the start of a more balanced period in terms of distribution of power in a multi-polar international system. Russia, as the largest heir to the USSR, made it clear to the West, particularly the U.S., that it would not hesitate to use force when

| 66 its interests were in jeopardy and no initiative could be taken in the international system in defiance of itself.

In the post-2008 period the resource wars among the great powers of the system surfaced. In the fight for resources, roughly speaking, while Russia, China and Iran formed the one axis, the U.S. along with the EU constituted the other axis. For example, the political repercussions called the "Arab Spring" are being influenced by the resource struggle between the major powers of the international system. Such that, the resource struggle as seen in the case of the Syrian crisis is carried out by proxy wars at this point.

Another crucial development that shaped this period was the financial crisis that started in the U.S. and took on a global dimension affecting the entire world. This crisis confirmed the fact that the key and decisive actors of the international system were the states. When large companies hoped for help from the government, their influence in international politics became debatable. Furthermore, when the global economy entered a period of recession, a risky period started for those economies that were dependent on domestic demand for growth, because they had difficulty in finding the proper resources to finance their growth.

\section{Strategy of Turkish Foreign Policy in the Post-2008}

In the post-2008 period it is possible to see the traces of a foreign policy strategy that Turkey had not experimented since the years of the Cold War. While the security pillar of its foreign policy approach is based on Western-oriented NATO alliance, neo-Ottomanism constitutes the political pillar. The architect of the neo-Ottomanist foreign policy approach is Foreign Minister Ahmet Davutoglu.

The period of stagnation experienced in Turkey-EU relations and the global crisis that broke out after 2008 paved the way for a new foreign policy strategy. Turkey-EU relations entered a period of serious decline since 2007. Having lost the EU anchor, Turkey started to follow a more autonomous foreign policy. Even a partially-transformed Turkey became the center of political, economic and diplomatic interest for its neighbors. ${ }^{66}$

Also, as the global crisis in 2008 severely shook the large economies, they had to turn inwards in order to deal with the economic and social problems. However, Turkey was affected by the global crisis to a relatively much lesser extent as a result of the reforms implemented particularly in the banking industry following the 2001 crisis.

The new foreign policy strategy neo-Ottomanism can be described, in analogy to Britain's commonwealth with its former colonies, as the establishment of an Ottoman Commonwealth of Nations in the former Ottoman territories in the leadership of Turkey.$^{67}$ Natural allies of this foreign policy approach would be those remnant states that lie within the corresponding geographical boundaries of the Ottoman Empire. Hence, Egypt, Syria, Libya, Jordan, Lebanon, Iraq and Palestine would be the natural allies of the new foreign policy approach. However, it is not realistic for the remnant states of the Ottoman Empire in the Balkans and North Africa to be natural allies as nearly all the states in the Balkans are members of the EU and several states in North Africa such as Tunisia, Morocco and Algeria are already part of the European Neighborhood Policy. Thus, Ankara had to confine its neo-Ottomanist strategy to the Middle Eastern states only. However, after the Arab Spring, Saudi Arabia and Qatar appear to be the new 
political allies of Turkey such that this situation is reminiscent of the Sunni sectarianism in foreign policy.

Neo-ottomanism that inspired Turkish foreign policy in the last period disregards the reality that "in the multivariate nature of social phenomena, when the variables that are outside our control affect each other independently the whole balance is disrupted instantly." 68 As a natural outcome of such an approach, it may be thought that Turkey wishes to establish a hegemonic relationship with the remnant Ottoman states over neo-Ottomanism. Because the historical backgrounds, social statuses, economic conditions and mutual relations of the states other than Turkey are taken as a fixed variable. Therefore, "as Turkey opens to the region and assumes a regulatory role, it does this without the appropriate intellectual accumulation on the historic, cultural and social structure of the region." ${ }^{99}$

An important feature of the new foreign strategy is the fact that the military and political alliance policies do not complement each other. For example, NATO member Turkey's signing of a military cooperation agreement with the dictator Omar al-Bashir Sudan ${ }^{70}$ was an inconsistency for Turkey which claims to adhere to the reference values of the modern world such as "liberal democracy, human rights, plurality, secularism, gender equality in its approach to its region." ${ }^{.11}$

Despite the neo-Ottomanist foreign policy approach, Ankara "The JDP does not assert Turkey's weight equally in the areas that were under Ottoman rule, namely the Balkans, the Caucasus and the Middle East." 72 Diplomatic data also supports this view. While Turkish foreign ministers made at least eight visits to Iran and Syria between November 2002 and April 2009, they visited Azerbaijan and Georgia only once. ${ }^{73}$ By reviewing the records at the Ministry of Foreign Affairs between February 2010 and February 2011, one can verify the weight of the diplomatic visits made to the Middle Easter countries.

After NATO's announcement of its new strategic concept at the 2010 Lisbon Summit and the Arab Spring, the relations with both Syria and Iran have started to deteriorate. Turkey would either pursue its ambitions in the Middle East or revert to its Western-oriented foreign policy approach. Turkey is likely to opt for the Western-oriented foreign policies due to the resulting instability in the region and the scale of the security issues it faces. ${ }^{74}$

After 2008 Turkish foreign policy is said to have two dimensions. The political dimension was tried to be pursued within the framework of ideological interest policy; the military dimension within the framework of complimentary alliance policy. Even until the new strategic concept of NATO was determined in 2010, the political alliance dimension took precedence in foreign policy. However, when Turkey was involved in the missile shield project, the military alliance dimension had the priority in the model of two clashing alliances.

\section{Objectives of Turkish Foreign Policy in the Post-2008}

The announcement of the new strategic concept by NATO on November 20, 2010 and the Arab Spring that started when a young man named Muhammed Buazizi set himself on fire on December 17, 2010 made it difficult for Ankara to define its foreign policy objectives. Until these developments, Ankara seemed to give priority to its foreign policy objectives aimed at establishing and developing an ideology which rendered the relations with Syria and Iran significant in this respect.

Turkey-Syria cabinet meetings held on October 13, 2009 in the cities of Gaziantep and Aleppo were the most striking step taken towards this goal. The statement made by Foreign Minister Davutoglu after the meeting "I announce that our common slogan is about a common destiny, common history and common future" was politically a manifestation of his desire for a regional integration with a neo-Ottomanist thought and idealism. ${ }^{75}$ 
Another striking development was the joint Border Forces Exchange Exercise carried out by Turkey and Syria on April 27-29, 2010 in the Yuksektepe and Inanli Border Outposts area. It was stated that the purpose of the exercise was to strengthen friendship, cooperation and trust between the elements of the land forces of both countries and increase the level of training and co-operability between the border troops. However, the exercise carried out with Syria seemed to have more than a symbolic meaning due to Ankara's vetoing of any kind of cooperation between 68 Israel and NATO. ${ }^{76}$

The most tangible outcome of the new-Ottomanist approach in foreign policy can be found in a statement made by Prime Minister Erdogan during a visit to Lebanon in 2010. He called for the establishment of a free movement zone consisting of Turkey, Lebanon, Libya, Syria, Jordan and even Iran by stating that "The EU says 'Schengen'. Why cannot we easily make a similar Schengen among us? It is not possible to understand this meaninglessness, this fear and this reservation." ${ }^{\prime 7}$ With this invitation, it appears that the intention was to take the first step towards the establishment of an Ottoman commonwealth in the Middle East.

In this period Turkey had to establish close relations with Iran, because unstable relations with Iran were an obstacle to the realization of Turkey's ambitions in the region. Also, Iran was one of the energy suppliers to Turkey. It was in Turkey's interest to maintain good relations with Iran due to its increasing energy demand. As known, the Iran's uranium enrichment program led to concerns in the international community, and even a military action against Iran was put on the table. Turkey made a proposal to the newly inaugurated Obama administration that it could act as a mediator between Iran and the U.S. Turkey began its mediation efforts but was unable to obtain any tangible results. Despite this, Ankara was insistent on the continuation of the process.

Indeed, in June 2010 Turkey as a temporary member of the UN Security Council voted against sanctions on Iran. Turkey stated that the reason for the "no" vote was to keep Iran from leaving the negotiation table. ${ }^{78}$ However, the West, particularly the U.S., was not pleased with Turkey's "no" vote, even when Russia and China voted "yes" at the UN Security Council. Moreover, Turkey vouched that Iran's nuclear program was being developed for peaceful purposes and stated that there was also a big nuclear problem in the region implying Israel. ${ }^{79}$ The position Turkey took in the face of these developments was compatible with its objective of implementing a Middle Eastern-centered foreign policy.

Since 2011 Turkey, starting to revert to a Western-oriented foreign policy, openly supported the dissidents militarily in the uprising in Syria and was obsessed with the overthrow of Assad. Turkey even tried to mobilize the international community to carry out a military intervention in Syria. Such attempts on the part of Turkey led to the questioning of its relations with Syria that had been maintained at the top level until recently and hence caused intense criticism of its foreign policy pursued to date.

Turkey's insistence on the overthrow of the Syrian regime was in conflict with the sloganized security strategy of Iran: Tehran's defense starts from Damascus. Furthermore, as a result of the deployment of NATO missiles in Malatya, the positive relations between Turkey and Iran entered a tense period. The sudden change in neighborly relations in foreign policy started threatening the security of Turkey. Naturally, Ankara had to give priority to those foreign policy objectives aimed at protecting its existence and security.

\section{Renewal or Revision in Turkish Foreign Policy Paradigm?}

In the New World Order era, as a medium-sized state, Turkey's Western-oriented foreign policy strategy was a rational and predictable choice. The main shift in this period's foreign policy paradigm is the adoption of complementary alliance policy rather than identical alliance policy. Therefore, one can speak of a gradual shift or revision in Turkey's foreign policy paradigm in the New World Order. In an international system where the SSBC expansionism and threat of 
communism were eliminated, it was obvious that the strategic contribution of Turkey would be limited. In the new era Turkey has adopted a new complementary alliance model that is mutually beneficial to itself and its allies and set an appropriate foreign policy vision. However, as the gap between its capacity and foreign policy ambitions remained unchanged, Turkey has been unable to reach its foreign policy vision.

Turkey adopted an assertive and active foreign policy in order to achieve its objectives set in accordance with its new foreign policy strategy. Naturally, diplomacy was the most utilized foreign policy instrument in active foreign policy. However, in the New World Order era the most obvious outcome of the revision of its foreign policy paradigm was the diversification of foreign policy instruments. Ankara had no reservations in interfering with the internal affairs of the third world countries to achieve its foreign policy objectives. For example, despite the central Iraqi government, Ankara was in direct contact with the Northern Iraqi leaders and even issued them red passports. Also, Ankara took a tough stance against the threats directed at its existence and security and made it very clear that it would not hesitate to use the war option with large-scale cross-border operations. As remembered, Turkey warned that it was determined to keep the war option on the table if Syria continued harboring the PKK leader Abdullah Ocalan. As a result, Syrian President Hafez Al Assad at that time had no other option but to expel the PKK leader from Syria.

In the New World Order era Turkey needed to use economic instruments effectively in its foreign policy. However, when Turkey was not even able to obtain financial resources for its own economy, it could not provide financial aid to other countries. Moreover, as its economy was fragile due to the economic crises experienced in 1994 and 1998, it is understandable why Turkey was not able to take advantage of economic instruments effectively in its foreign policy.

In the post-September 11 period Turkey continued to pursue its Western-oriented foreign policy. As a result of the international security conditions, Turkey gained strategic importance in the international system and became a legitimizing and bridging actor of the West in the East. Generally speaking, it can be stated that Ankara read the September 11 conditions correctly and took advantage of the available opportunities wisely. In this period the most notable change is the addition of the identity dimension to the Turkish foreign policy paradigm. Thus, Turkey's star has risen both as a Muslim and Western actor, and it has become one of the key states in the international system despite being a medium-size state.

Turkey acted as a mediator between Israel and Syria that are unlikely to sit at the same table. Similarly, after the Saddam regime, Turkey simultaneously pursued diplomatic contacts with the UN Security Council, the Organization of Islamic Conference (OIC), Iraq's neighbors, and ethnic and religious groups in Iraq in order to contribute to Iraq's political development. ${ }^{80}$ Second, Turkey was able to increase its influence in the international organizations. The NATO and OIC summits were held in Turkey in 2003 and Turkey was invited to the African Union in 2005 as an observer country. ${ }^{81}$ In the same year Ekmeleddin Ihsanoglu was the first Secretary General elected by a democratic selection process. However, after Turkey started accession talks on November 3, 2005, the EU process slowed down, and as a result the EU-centered diplomacy has not performed well in 2007 and beyond. Indeed, the establishment of the Ministry for European Union Affairs took place only in 2011. Of course, in this period the prejudiced attitudes of the EU member states played an important role in the inadequate performance of Turkey's EUcentered diplomacy.

The political influence tool for Turkey that made its mark on the period is the cochairmanship of the Alliance of Civilizations Project. Turkey, culturally an Eastern, politically a Western state, would be the most suitable country to lead the project. ${ }^{82}$ Ankara already believed that "Its unique historical, political and social experience would confer both a role and responsibility on Turkey to promote peace and security." 83 The initiative taken within the framework of the Alliance of Civilizations pointed to an instrumental differentiation in the traditional Turkish foreign policy; because "Turkey would assume the position of the 


\section{H. Burç Aka}

spokesperson of the Islamic world and carry out a leading role in a global initiative for the first time. ${ }^{84}$

In the post-2008 period Turkey tried to renew its foreign policy paradigm rather than revise it. For the first time since the Cold War era, foreign policy has been a complementary part of the government's domestic political ideology and identity in this period. The most distinctive feature of this period is Turkey's attempt to implement an alliance policy that serves the ideological interests. Ankara's renewal of its foreign policy paradigm was an ideological preference rather than an adaptation to the global systemic change. However, a foreign policy approach which was Western-oriented in a military sense but politically anti-western eventually bogged down as a result of the inherent contradiction it contained. Indeed, in this period the radical shift in the foreign policy paradigm has been very costly. For example, the perception that Turkey has entered a period of "just problem" with its Eastern and Southern border neighbors and broke away from the West is very widespread.

\section{Conclusion}

This article evaluated the paradigm shift in Turkey's foreign policy in the light of the post-Cold War characteristics. Undoubtedly, the studies that examine the paradigm shift in Turkey's foreign policy at different levels and units provide important information for analysts and make theoretical studies more consistent.

The main proposal of the article is that Turkey has not abandoned its Western-oriented foreign policy paradigms. With the Russian Federation recovering its strength, the equilibrium in the international system has been reached and the capacity of the classical balance of power to produce instability has increased further. As seen in the cases of Syria and Ukraine, the settlement of international crises can lead to painful processes and have serious consequences. In such an environment Turkey's claim to be a major actor, given its present strength, cannot go any further than being a long-term objective as there is an obvious disparity between its strength and claims.

The developments experienced since the last quarter of 2013 signal that Turkey tries to return to the complimentary alliance policy with the West. When Turkey is integrated with NATO militarily, the EU Council politically and the EU economically, it has to set its foreign policy paradigm in the new era from the perspective of a full EU membership. If Turkey were to achieve universal democratic standards, the rule of law at high standards and production-based growth model, it would be able to pursue its ambition of becoming not only a regional actor but also an international one.

\section{Notes}

\footnotetext{
${ }^{1}$ Bülent Aras, "Turkey's Rise in the Greater Middle East: Peace-Building in the Periphery," Journal of Balkan and Near Eastern Studies 11 (2009); Hakan Fidan, "A Work in Progress: The New Turkish Foreign Policy," Middle East Policy 20 (2013).

${ }^{2}$ Kemal Kirişçi, "The Transformation of Turkish Foreign Policy: The Rise of the Trading State," New Perspectives on Turkey 40 (2009); Mustafa Kutlay, "Economy as the 'Practical Hand' of 'New Turkish Foreign Policy’: A Political Economy Explanation,” Insight Turkey 13 (2011).

${ }^{3}$ Tarık Oğuzlu and Mustafa Kibaroğlu, "Is the Westernization Process Losing Pace in Turkey: Who's to Blame?," Turkish Studies 10 (2009); Lerna Yanık, “Constructing Turkish 'Exceptionalism': Discourse of Liminality and Hybridity in post-Cold War Turkish Foreign Policy,” Political Geography 30 (2011).

${ }^{4}$ Meliha B. Altunış1k and Lenore G. Martin, "Making Sense of Turkish Foreign Policy in the Middle East under AKP," Turkish Studies 12 (2011); Ahmet Sözen, "A Paradigm Shift in Turkish Foreign Policy: Transition and Challenges," Turkish Studies 11 (2010); Ziya Öniş, "Multiple Faces of the 'New' Turkish Foreign Policy: Underlying Dynamics and a Critique,” Insight Turkey 13 (2011).
} 
5 Güneş Murat Tezcür and Alexandru Grigorescu, “Activism in Turkish Foreign Policy: Balancing European and Regional Interests," International Studies Perspectives 15 (2014).

${ }^{6}$ Anthony Best, Jussi M. Hanimaki, Joseph A. Maiolo and Kirsten Schulz, International History of the Twentieth Century (New York: Routledge, 2006); Michael Cox, "From Cold War to the War on Terror," in The Globalization of World Politics, ed. John Baylis and Steve Smith (Oxford: Oxford University Press, 2003).

${ }^{7}$ George Friedman, "Beyond the Post-Cold War," Geopolitical Weekly (2013), accessed March 4, 2014, http://www.stratfor.com/weekly/beyond-post-cold-war-world\#axzz2VX3EXnM9 (Erişim: 04 Nisan 2013).

${ }^{8} \mathrm{H}$. Burç Aka, Security Dimension of European Integration: In the Context of Changing International System (Saarbrücken: Lambert Academic Publishing, 2010), 88.

9 Ersin Kalaycıŏlu, "Yeni Dünya Düzeni ve Türk Dış Politikası (The New World Order and Turkish Foreign Policy)," in Türk Dış Politikasının Analizi, ed. Faruk Sönmezoğlu (İstanbul: Der Yayınları, 1998), 633.

10 Zbigniew Brezinski, “Büyük Satranç Tahtası: Amerika'nın Küresel Üstünlüğü ve Bunun Jeostratejik Gereklilikleri (The Grand Chessboard: American Primacy and Its Geo-strategic Imperatives)," trans. Yelda Türedi (İstanbul: İnkılap Yayınları,2005), 26.

${ }^{11}$ Henry Kissinger, "Diplomasi (Diplomacy)", trans İbrahim H. Kurt (İstanbul: Türkiye İş Bankası Kültür Yayınlar1, 2006), 61.

12 The Merriam-Webster Online Dictionary, http://www.merriam-webster.com/dictionary/paradigm.

${ }^{13}$ Alper Taşdelen, "Dış Politikada Paradigma (Paradigm in Foreign Policy)," Radikal Gazetesi, June 15, 2012, accessed December 18, 2013, http://www.radikal.com.tr/yorum/dis_politikada_paradigma-1091187.

${ }^{14}$ Mustafa Aydin, "Turkish Foreign Policy at the End of the Cold War: Roots and Dynamics," Turkish Yearbook of International Relations 36 (2005): 4- 5.

${ }^{15}$ For state centric foreign policy analysis, see George Modelski, A Theory of Foreign Policy, (London: Pall Mall Press, 1962); Kalevi J. Holsti, International Politics: A Framework for Analysis (4th Edition), (London: Prentice Hall, 1983); James N. Rosenau, "The Study of Foreign Policy," in World Politics: An Introduction, ed. James N. Rosenau, Kenneth W. Thomson and Gavin Boyd (New York: Free Press, 1972). For non-state centric foreign policy analysis, see Martin Hollis and Steve Smith, Explaining and Understanding International Relations, (Oxford: Clarendon Press, 1990); Richard W. Mansbach, The Global Puzzle, Issues and Actors In World Politics, (New York: Houghton Mifflin, 2000); Bruce Russet, Harvey Starr and David Kinsella, World Politics: The Menu For Choice (8th Edition), (Belmont: Thomson Wadsworth, 2006).

${ }^{16}$ Modelski, A Theory of Foreign Policy.

${ }^{17}$ Holsti, International Politics.

${ }^{18}$ Rosenau, "The Study of Foreign Policy".

${ }^{19}$ Hans Morgenthau, "Politics Among Nations: The Struggle Power and Peace” New York: Alfred A. Knopf, 1967), $175-187$.

${ }^{20}$ Charles O Jr. Learche and Abdul A. Said, Concept of International Politics, 2ndEdition (New Jersey: Prentince-Hall, 1970), 25.

21 "Official Text: The Alliance's New Strategic Concept," NATO, 1991.

22 Margaret Thatcher, "Speech to Czechoslovak Federal Assembly," 1990, accessed April 24, 2013 http://chnm.gmu.edu/1989/archive/files/thatcher-speech-9-18-90-9890abc557.pdf; William Jefferson Clinton "Assessing the United Nations at 50," 1995, accessed April 24, 2013, http://www.defencelink.mil/speeches/speech.aspx?speechid=993.

23 Amikam Nachmani, (Manchester and New York: Manchester University Press 2003),1; William Hale, Turkish Foreign Policy 1774 -2000, (London: Frank Cass Publishers, 2002)

${ }^{24}$ Philip Robbins, "Turkish Foreign Policy Under Erbakan," Survival: Global Politics and Strategy 39 (1997): 97.

25 Baskın Oran, "Dönemin Bilançosu (An Accounting of An Era)," Türk Dış Politikası: Kurtuluş Savaşından Bugüne Olgular, Belgeler, Yorumlar Vol. 2: 1980 - 2001 (Turkish Foreign Policy: From the Turkish War of Liberation to Today, Facts, Documents, Comments: 1980 - 2001) ed. Baskin Oran (İstanbul: İletişim Yayınları, 2001), 210; William Hale, Turkish Foreign Policy 1774 - 2000, (London: Franc Cass Publishers, 2002), 192; Nachmani, Turkey Facing A New Millennium: Coping with Intertwined Conflicts, 7.

${ }^{26}$ Kemal Kirişçi, “Uluslararası Sistemde Değişmeler ve Türk Dış Politikasının Yeni Yönelimleri (Changes in the International System and New Directions in Turkish Foreign Policy), " trans. Burak Gülboy in Türk Dış Politikasının Analizi, ed. Faruk Sönmezoğlu (İstanbul: Der Yayınları, 1998), 616.

("Changes in the International System and New Directions in Turkish Foreign Policy")

${ }^{27}$ Nasuh Uslu, Turkish Foreign Policy in the Post-Cold War Period, (New York: Nova Publishers, 2004$), 4$. 
28 "Official Text: The Alliance's New Strategic Concept," NATO, 1991.

${ }^{29}$ Sabri Sayar1, "Turkish Foreign Policy in the Post-Cold War Era: The Challenges of Multi-Regionalism," Journal of International Affairs 54 (2000): 173.

${ }^{30}$ Şükrü Gürel, "A General Appraisal Of Current Turkish Foreign Policy" in Turkey at the Threshold of the 21th Century, ed. Mustafa Aydın (Ankara: International Relations Foundation, 1998), 12.

| $72 \quad{ }^{31}$ Kalaycıoğlu, "Yeni Dünya Düzeni ve Türk Dış Politikası," 642.

${ }^{32}$ Şükrü Elekdağ “2 1/2 Wars," Perceptions 1 (1996), accessed May 20, 2013, http://sam.gov.tr/wpcontent/uploads/2012/02/SukruElekdag.pdf.

${ }^{33}$ See more details: Murhaf Jouejati, "Water Politics as High Politics: The Case of Turkey and Syria,"in Reluctant Neighbor: Turkey's Role in the Middle East, ed. Henri J. Bakery (Washington: Institute of Peace Press, 1996).

${ }^{34}$ Gülden Ayman and Nurşin Güney Ateşoğlu, "Değissen Uluslararası Koşullarda Strateji, Türkiye ve Komşuları (Strategy in the Changing International Conditions, Turkey and Its Neighbors), ” in Türk Dış Politikasının Analizi, ed. Faruk Sönmezoğlu (İstanbul: Der Yayınları, 1998), 435.

${ }^{35}$ Ayman and Ateşoğlu, "Değişen Uluslararası Koşullarda Strateji, Türkiye ve Komşuları," 437 - 439.

${ }^{36}$ John Tirman, "Improving Turkey's 'Bad Neighborhood' Pressing Ankara for Rights and Democracy," World Policy Journal 15 (1998): 61.

${ }^{37}$ Elekdağ "2 1/2 Wars," 38.

${ }^{38}$ Mümtaz Sosyal, "The Future of Turkish Foreign Policy," in The Future of Turkish Foreign Policy, ed. Leonere G. Martin and Dimitris Keridis (Cambridge: The MIT Press, 2004), 41- 43.

${ }^{39}$ Panayotis J. Tsakonas and Thanos P. Dokos "Greek-Turkish Relations in the Early Twenty-first Century: A View From Athens," in The Future of Turkish Foreign Policy, ed. Leonere G. Martin and Dimitris Keridis (Cambridge: The MIT Press, 2004), 107.

${ }^{40}$ William Hale, Turkish Foreign Policy 1774 - 2000, 288.

${ }^{41}$ Ibid., 291.

${ }^{42}$ Ibid., 287 - 295.

${ }^{43}$ Mustafa Aydın "Kafkasya ve Orta Asya'yla İlişkiler (Relations With The Caucuses and Central Asia)," Türk Dış Politikası: Kurtuluş Savaşından Bugüne Olgular, Belgeler, Yorumlar Vol. 2: 1980 - 2001, ed. Baskın Oran (İstanbul: İletişim Yayınları, 2001), 432 - 433.

${ }^{44}$ Necdet Pamir, "Bakü-Tiflis-Ceyhan Boru Hattı'nda Son Durum (The Latest on the Baku-Tbilisi-Ceyhan Crude Oil Pipeline)," Panorama Dergisi 3 (2004): 5.

${ }^{45}$ Ibid., 2.

46 “Türkiye'nin Enerji Stratejisi (Turkey's Energy Strategy)," Republic of Turkey Ministry of Foreign Policy, accessed August 15, 2013, http://www.mfa.gov.tr/turkiye_nin-enerji-stratejisi.tr.mfa.

${ }^{47}$ Meltem Müftüler Baç, “Turkey’s Predicament in the Post-Cold War Era,” Futures 28 (1996): 257.

${ }^{48}$ Beril Dedeoğlu, "Dünden Yarına Türkiye-Avrupa Birliği İlişkileri (The EU-Turkey Relations from Yesterday to Tomorrow)," Siyasa 1 (2005): 37 - 38. Beril Dedeoğlu,

49 "The Alliance's New Strategic Concept," NATO, 1999.

${ }^{50}$ Zeynep Atikkan, "Amerikan Cinneti: 11 Eylül Amerika'yı Nasıl Değiştirdi? (The American Insanity: How Did September 11 Change America?)," (İstanbul: Yapı Kredi Yayınları, 2006).

${ }^{51}$ Cengiz Çandar, "Turkish Foreign Policy and the War in Iraq," in The Future of Turkish Foreign Policy, ed. Leonere G. Martin and Dimitris Keridis (Cambridge: The MIT Press, 2004), 51.

${ }^{52}$ Ibid.

${ }^{53}$ Ziya Öniş, "Turkey and the Middle East after September 11: The Importance of the EU Dimension,” Turkish Policy Quarterly 2 (2003): 5, accessed December 21, 2013, http://www.turkishpolicy.com/images/stories/2003-04-EUforeignpolicy/TPQ2003-4-onis.pdf.

${ }^{54}$ Soli Özel, “Arap Baharı ile Ortadoğu'da Değişen Dış Politika Dengeleri (Changing Balances in Foreign Policy in the Middle East with the Arab Spring)," Perspectives 12 (2012): 60.

${ }^{55}$ Karabekir Akkoyunlu, Kalypso Nicolaidis and Kerem Öktem, The Western Condition: Turkey, the U.S. and the EU in the New Middle East, (Oxford: South East European Studies at Oxford, 2013), 25.

${ }^{56}$ Meltem Müftürler Baç, "Turkey's Accession to the European Union: Institutional and Security Challenges," Perceptions 9 (2004): 39.

${ }^{57}$ Nathalie Tocci, "Let's talk Turkey! U.S. Influence on EU-Turkey Relations," Cambridge Review of International Affairs 25 (2012): 403.

${ }^{58}$ Serhat Güvenç and Soli Özel, "NATO and Turkey in the Post-Cold War World: Between Abandonment and Entrapment," Southeast European and Black Sea Studies 12 (2012): 542.

${ }^{59}$ Prime Minister Erdogan stated that the EU will gain a bridge between itself and the 1.5 billion Islamic world with the accession of 99\% Muslim Turkey to the EU. See Guardian, September 30, 2005. 
${ }^{60}$ Ahmet Davutoğlu, "Turkey's Zero-Problems Foreign Policy,”, Foreign Policy (2010), accessed February 8, 2014, http://www.foreignpolicy.com/articles/2010/05/20/turkeys_zero_problems_foreign_policy

${ }^{61}$ Emre Erşen, "Türk Dış Politikasında Avrasya Yönelimi ve Şanghay İşbirliği Örgütü (Eurasian Orientation in Turkish Foreign Policy and the Shanghai Cooperation Organization)," Ortadoğu Analiz 5 (2013): 19.

${ }^{62}$ Meltem Müftüler Baç, “The European Union’s Accession Negotiations with Turkey from a Foreign Policy Perspective,” Journal of European Integration 30 (2008): 69.

${ }^{63}$ Ibid., 71.

${ }^{64}$ Bülent Aras, “Turkey's Rise in the Greater Middle East: Peace-Building in the Periphery," Journal of Balkan and Near Eastern Studies 11 (2009): 32 - 33.

${ }^{65}$ Bülent Aras, "Turkey and Middle East Security," (2005) accessed June 10, 2013 http://www.globalpolitician.com/2369-turkey

${ }^{66}$ Serhat Güvenç and Soli Özel, "NATO and Turkey ...”, 542.

${ }^{67}$ Jackson Diehl, "How WikiLeaks Cables Capture 21st-Century Turkey," Washington Post, December 5, 2010.

${ }^{68}$ Cüneyt Ülsever, "Bir Ahmet Davutoğlu Analizi (An Ahmet Davutoğlu Analysis)," Yurt Gazetesi, July $26,2012$.

${ }^{69}$ Ali Bulaç “Kritiğe Muhtaç Diş Politika (A Foreign Policy in Need of A Critique)," Zaman Gazetesi, October 6, 2011.

${ }^{70}$ Law No. 6441 Date of Adoption 26.02.2103, Official Gazette, No.28588, March 15, 2013.

${ }^{71}$ Kadri Gürsel, “Davutoğlu'nun İnfilak Ederek Dağılması (Davutoglu's Breakdown After Exploding with Rage)," Milliyet, July 8, 2012.

72 Soner Çagaptay, “The AKP's Foreign Policy: The Misnomer of Neo-Ottomanism,” Washington Institute Policy Analysis (2009), accessed April 3, 2013, http://www.washingtoninstitute.org/policy-

analysis/view/the-akps-foreign-policy-the-misnomer-of-neo-ottomanism

${ }^{73}$ Ibid.

${ }^{74}$ Ian O Lesser , “Turkey's Third Wave-And the Coming Quest for Strategic Reassurance,” (2011), accessed February 2, 2013, http://www.gmfus.org/wpcontent/blogs.dir/1/files_mf/1321550150_magicfields_attachment_1_1.pdf

75 Veysel Ayhan, “Türkiye-Suriye İlişkilerinde Yeni Bir Dönem: Yüksek Düzeyli Stratejik İşbirliği Konseyi (A New Era in Turkey-Syria Relations: High Level Strategic Cooperation Council)," Orta Doğu Analiz 1 (2009): 32.

${ }^{76}$ Henri J. Barkey, "Turkish-Iranian Competition after the Arab Spring," Survival: Global Politics and Strategy 54 (2012): 144.

${ }^{77}$ Habertürk, November 10, 2010.

${ }^{78}$ Karen Kaya, “Turkey - Iran’s Relations After Arab Spring,” Foreign Military Studies Office (2012), accessed May 16, 2013, http://fmso.leavenworth.army.mil/documents/Turkey-Iran.pdf

${ }^{79}$ Barkey, "Turkish-Iranian Competition after the Arab Spring," 146.

${ }^{80}$ Aras, "Turkey's Rise in the Greater Middle East...," 35-40.

${ }^{81}$ Ahmet Davutoğlu, “Turkey’s Foreign Policy Vision: An Assessment of 2007,” Insight Turkey 11 (2008): 82

${ }^{82}$ Ali Balcı and Nebi Miş, "Turkey’s Role in the Alliance of Civilizations: A New Perspective in Turkish Foreign Policy?,” Turkish Studies 9 (2008): 392.

${ }^{83}$ Abdullah Gül, "Turkey's Role in a Changing Middle East Environment," Mediterranean Quarterly 15 (2004): 3.

${ }^{84}$ Balcı and Miş, “Turkey’s Role in the Alliance of Civilizations...," 400. 